RESEARCH NOTE

\title{
Detection of antibodies to Neospora caninum in moose (Alces alces): the first report in Europe
}

\author{
Bożena Moskwa ${ }^{1}$, Katarzyna Goździk ${ }^{1}$, Justyna Bień ${ }^{1}$, Aleksandra Kornacka ${ }^{1}$, Aleksandra Cybulska ${ }^{1}$, \\ Katarína Reiterová ${ }^{2}$ and Wladysław Cabaj ${ }^{1}$
}

\author{
${ }^{1}$ Witold Stefański Institute of Parasitology, Polish Academy of Sciences, Warsaw, Poland; \\ ${ }^{2}$ Institute of Parasitology, Slovak Academy of Sciences, Košice, Slovakia
}

\begin{abstract}
Neospora caninum Dubey, Carpenter, Speer, Topper et Uggla, 1988 is a protozoan parasite originally reported as a major cause of bovine abortions worldwide. It is documented that the parasite is widely spread among non-carnivorous cervids. The purpose of this study was to investigate the seroprevalence of $N$. caninum in moose (Alces alces Linnaeus). Blood samples collected in 2010 and 2012 in the northeastern Poland were tested for antibodies to $N$. caninum by agglutination test (NAT), a commercial competitive screening enzyme-linked immunosorbent assay (cELISA) and enzyme-linked immunoassay (ELISA). Sera that gave a positive result were further investigated by western blot (WB) analysis to verify the presence of antibodies. Antibodies to $N$. caninum were detected in one of seven moose. The antibody titer was confirmed by NAT $(1: 1280)$, cELISA $(\mathrm{I}=91 \%)$ and ELISA $(\mathrm{OD}=0.736)$. The main immunodominant antigens detected by WB were 120, 70, 55, 35 and $16 \mathrm{kDa}$ proteins. This is the first evidence of $N$. caninum seropositivity in moose living in a natural environment in Europe.
\end{abstract}

Keywords: Apicomplexa, elk, wildlife, serology, Poland

Neospora caninum Dubey, Carpenter, Speer, Topper et Uggla, 1988 is a protozoan parasite originally reported in dogs (Dubey et al. 1988) and commonly diagnosed in bovine abortions worldwide (Goodswen et al. 2013).

In Europe, the presence of $N$. caninum has been confirmed serologically in red deer (Cervus elaphus Linnaeus), roe deer (Capreolus capreolus Linnaeus), fallow deer (Dama dama Linnaeus), sick deer (Cervus nippon Temminck) and the European bison (Bison bonasus bonasus Linnaeus) (Cabaj et al. 2005, Bártová et al. 2007, Goździk et al. 2010, Bień et al. 2012).

The purpose of this study was to investigate the presence of antibodies against $N$. caninum in moose (Alces alces Linnaeus) in the north-east region of Poland because no data exist on the occurrence of $N$. caninum in this host in Europe.

Blood samples collected from seven moose were used as the basis of the study. Six of the moose had been hunted for scientific purposes in November 2010 in the Augustowska Forest (Augustów Voivodship), the Biebrza Marshes (Rajgród Voivodship) and Ełk Voivodship with the authorization of the Ministery of the Environment. One of the moose examined in 2012 was hunted in the Białowieża National Forest. Data concerning sex, age and health of caught animals were not available.
Agglutination test (NAT) was performed according to Romand et al. (1998) with $N$. caninum ( $\mathrm{NC1}$ isolate) whole tachyzoite antigen. In brief, $50 \mu 1$ of $0.2 \mathrm{M}$ mercaptoethanol in PBS was distributed in each well with a two-fold serial dilutions of sera were performed. The sera were screened at $1: 20$ serum dilution and samples were diluted up to $1: 10240$. Tachyzoites concentration was adjusted at $2 \times 10^{4} \mu \mathrm{l}^{-1}$. After the sera had been diluted, $50 \mu \mathrm{l}$ of $N$. caninum antigen suspension was distributed to each well. Every assay included two negative and one positive controls. The negative control comprised the antigen alone and serum sample from negative cattle, whereas the positive control comprised the serum from positive cattle.

The sera were also screened for $N$. caninum-specific antibodies with a commercial competitive screening enzyme-linked immunosorbent assay (c-ELISA) (VMRD, Pullman, WA) was applied according to the manufacturers' instructions. The percentage of inhibition was calculated as follows: \% $\mathrm{I}=100$ [1 - (sample OD $\div$ negative control OD)]. When the sample produced $\geq 30 \%$ inhibition, (\% I) it was regarded as positive.

Enzyme-linked immunoassay (ELISA; IDEXX Laboratories Inc., Westbrook, ME) was performed with some modifications (Bień et al. 2012). Peroxidase-labeled affinity-purified antibody to deer IgG $(\mathrm{H}+\mathrm{L})$ (KPL, Gaithersburg, MD) was used as a second antibody. The ELISA cut-off was calculated as the mean of the negative sera (OD) plus three standard deviations (SD) (Moskwa et al. 2009).

Indirect ELISA (ID Screen ${ }^{\circledR}$ Toxoplasmosis Indirect Multispecies, ID VET, Montpellier, France), was performed to screen serum samples or T. gondii-specific antibodies. According to the manufacturer's instruction, the $\mathrm{S} / \mathrm{P}$ percentage was calculated as follows: $\mathrm{S} / \mathrm{P}=100$ [(sample OD - negative control OD) / (positive control OD - negative control OD)]. Sample presenting S/P greater than or equal to $50 \%$ the sample is considered positive.

Sera that gave a positive result were further investigated by western blot (WB) to verify the presence of antibodies. SDSpolyacrylamide gel electrophoresis and WB analysis were performed according to Cabaj et al. (2005) using the Bio-Rad System. For the WB, the antigen was prepared from $N$. caninum tachyzoites of the $\mathrm{NC} 1$ isolate propagated in Vero cells. Positive and negative serum samples from cattle were used as a control.

For NAT, all sera were screened at $1: 20$ and only one was screened to $1: 1280$ dilution. For c-ELISA, the presence of the

Address for correspondence: B. Moskwa, Witold Stefański Institute of Parasitology of the Polish Academy of Sciences, 00-818 Warszawa, Twarda 51/55, Poland. Phone: +48 22 6978995; E-mail: moskwa@twarda.pan.pl 


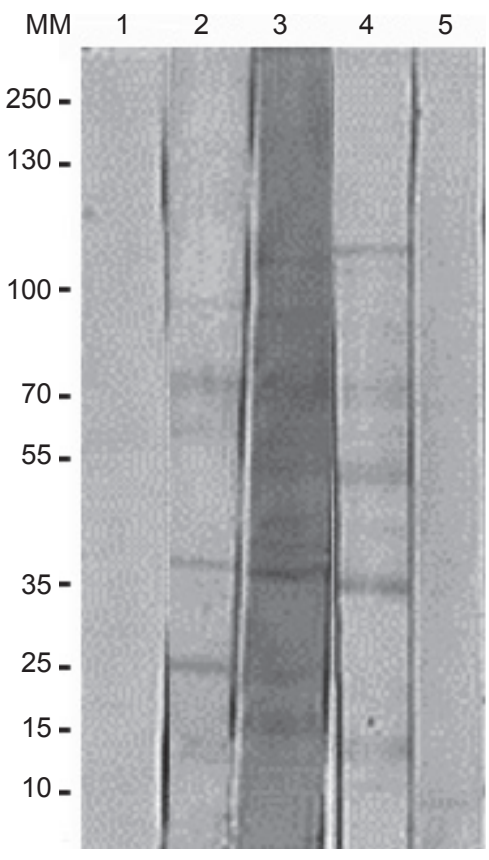

Fig. 1. Western Blot analysis of antibody responses of cows and moose against Neospora caninum (NC1) antigen: line $\mathbf{1}$ - negative cow; line 2, 3 - positive cows; line $\mathbf{4}$ - positive moose; line 5 - negative moose; $\mathrm{MM}$ - molecular marker.

antibody against $N$. caninum was confirmed in one of the seven examined samples ( $I=91 \%)$. The presence of the antibody against $N$. caninum detected by ELISA was confirmed in three of the seven examined samples. The OD values were found to be $0.736,0.151$ and 0.156 , respectively. The negative and positive control sera had OD values of $0.12(\mathrm{SD}=0.012)$ and 0.872 $(\mathrm{SD}=0.13)$, respectively (the ELISA cut-off OD level was 0.132). Three of the examined sera had an OD value higher than the cut-off. Antibodies to N. caninum were detected in moose from the Ełk Voivodship $\left(22^{\circ} 21^{\prime} \mathrm{E} ; 53^{\circ} 29^{\prime} \mathrm{N}\right)$.

Western Blot analysis revealed seropositivity against immunodominant $N$. caninum antigens of $120,70,55,35$, and $16 \mathrm{kDa}$ only in one serum sample (Fig. 1). Some additional protein bands were observed between 55 and $70 \mathrm{KDa}$ and approximately $100 \mathrm{kDa}$. WB revealed a very similar protein pattern for serum samples from moose and cattle. However, for the sera of cows, a very distinct additional $25 \mathrm{kDa}$ band was observed.
Additional screening of moose sera for the presence of Toxoplasma gondii revealed the presence of $T$. gondii antibodies in two of seven examined samples. The S/P percentage were found to be $106 \%$ and $114 \%$. As a consequence of a small number of animals examined in this study, future investigations will need a larger population sample size to allow a valid interpretation of the results. The results published by Vikøren et al. (2004), Jokelainen et al. (2010) or Malmsten et al. (2011) show that T. gondii infection is widely spread in the Norwegian, Finish and Swedish moose population ( $12.6 \%, 9.6 \%$ and $20 \%$, respectively).

In the present study, multiple serological tests, namely NAT, cELISA, ELISA and WB, were used and they confirmed that one moose was seropositive. The high accuracy of the results could be due to the fact that the serum samples were collected soon after the death of the animals; this is an important point because the length of the time from the death of animal, among other factors, contribute to the degradation of serum proteins (Dubey et al. 2009).

Only very few reports on the presence of $N$. caninum antibodies in moose are available, especially from the USA (Alas$\mathrm{ka}$ - seroprevalence 0.05-2.5\%; Illinois - 13\%; Gondim et al. 2004, Dubey and Thullez 2005, Stieve et al. 2010). In Sweden, where moose are one of the most extensively hunted cervids, none of 417 moose serum samples was found to be positive (Malmsten et al. 2011). No N. caninum antibodies were detected in any of 13 moose from zoos in the Czech and Slovak Republics (Sedlák and Bártová 2006). The serological results of the present study indicate that moose in Poland may be exposed to $N$. caninum infection. To our knowledge, this is the first report confirming the presence of antibodies against $N$. caninum in moose living in a natural environment in Europe.

Our earlier studies revealed that the WB analysis performed on serum samples from cattle, European bison and fallow deer show a very similar protein pattern for all analysed strips, a highly distinct additional band of approximately $25 \mathrm{kDa}$ was observed in serum samples from cows, fallow deer and European bison (Cabaj et al. 2005, Bień et al. 2012). This band was not visible in any of the WB strips for serum samples from moose serum.

Acknowledgements. Samples were obtained as part of a project supported by the National Science Centre, Grant No. NN308 585740. The study was partially supported by the Polish-Slovak Joint Research Project 'Observation of serious protozoonoses (neosporosis and toxoplasmosis) in domestic and sylvatic cycle'.

\section{References}

Bártová E., Sedlák K., Pavlík I., Literák I. 2007: Prevalence of Neospora caninum and Toxoplasma gondii antibodies in wild ruminants from the countryside or captivity in the Czech Republic. J. Parasitol. 93: 1216-1218.

Bień J., Moskwa B., Bogdaszewski M., Cabaj W. 2012: Detection of specific antibodies anti-Neospora caninum in the fallow deer (Dama dama). Res. Vet. Sci. 92: 96-98.

Cabaj W., Moskwa B., Pastusiak K., Gill J. 2005: Antibodies to Neospora caninum in the blood of European bison (Bison bonasus bonasus L.) living in Poland. Vet. Parasitol. 128: 163-168.

Dubey J.P., Carpenter J.L., Speer C.A., Topper M.J., Uggla A. 1988: Newly recognized fatal protozoan disease of dogs. J. Am. Vet. Med. Assoc. 192: 1269-1285.

Dubey J.P., Jenkins M.C., Kwok O.C., Zink R.L., Michalski M.L., Ulrich V., Gill J., Carstensen M., Thulliez P. 2009: Seroprevalence of Neospora caninum and Toxoplasma gondii antibodies in white-tailed deer (Odocoileus virginianus) from Iowa and Minnesota using four serologic tests. Vet. Parasitol. 161: 330-334.

Dubey J.P., Thulliez P. 2005: Prevalence of antibodies to $\mathrm{Ne}$ ospora caninum in wild animals. J. Parasitol. 91: 1217-1218.

Gondim L.F., McAllister M.M., Mateus-Pinilla N.E., Pitt W.C, Mech L.D, Nelson M.E. 2004: Transmission of Neospora caninum between wild and domestic animals. J. Parasitol. 90: 1361-1365. 
Goodswen S.J., Kennedy P.J., Ellis J.T. 2013: A review of the infection, genetics, and evolution of Neospora caninum: from the past to the present. Infect. Genet. Evol. 13: 133-150.

Goździk K., Jakubek E.B., Bıörkman C., Bień J., Moskwa B., Cabas W. 2010: Seroprevalence of Neospora caninum in free living and farmed red deer (Cervus elaphus) in Poland. Pol. J. Vet. Sci. 13: 117-120.

Jokelainen P., Näreaho A., Knaapi S., Oksanen A., Rikula U., Sunura A. 2010: Toxoplasma gondii in wild cervids and sheep in Finland: north-south gradient in seroprevalence. Vet. Parasitol. 171: 331-336.

Malmsten J., Jakubek E.B., Bıörkman C. 2011: Prevalence of antibodies against Toxoplasma gondii and Neospora caninum in moose (Alces alces) and roe deer (Capreolus capreolus) in Sweden. Vet. Parasitol. 17: 275-280.

Moskwa B., Bien J., Cabaj W., Korinková K., Koudela B., Stefaniak J. 2009: The comparison of different ELISA procedures in detecting anti-Trichinella $\mathrm{IgG}$ in human infections. Vet. Parasitol. 159: 312-315.
Romand S., Thulliez P., Dubey J.P. 1998: Direct agglutination test for serologic diagnosis of Neospora caninum infection. Parasitol. Res. 84: 50-53.

Sedlák K., Bártová E. 2006: Seroprevalence of antibodies to Neospora caninum and Toxoplasma gondii in zoo animals. Vet. Parasitol. 136: 223-231.

Stieve E., Beckmen K., Kania S.A., Widner A., Patton S. 2010: Neospora caninum and Toxoplasma gondii antibody prevalence in Alaska wildlife. J. Wildl. Dis. 46: 348-355.

Vikøren T., Tharaldsen J., Fredriksen B., Handeland K. 2004: Prevalence of Toxoplasma gondii antibodies in wild red deer, roe deer, moose, and reindeer from Norway. Vet. Parasitol. 120: 159-169.

Received 25 July 2013

Accepted 25 October 2013 